\title{
Effect of Different Levels, Sources and Methods of Nitrogen Application on Growth and Yield of Rice (Oryza sativa L.)
}

\author{
Ravindra Meena*, Janardan Yadav and Giriraj \\ Department of Soil Science and Agricultural Chemistry, Institute of Agricultural Sciences, \\ Banaras Hindu University, Varanasi, UP-221005, India \\ *Corresponding author
}

\section{A B S T R A C T}

\section{Keywords}

Rice, Polymer Coated Urea (PCU), Normal urea, Slow releasing fertilizer

Article Info

Accepted:

04 March 2018

Available Online:

10 April 2018
A field experiment was conducted on alluvial soil to study the effect of growth and yield of rice as influenced by different levels of nitrogen and method of basal and split application of nitrogen at Banaras Hindu University during kharif season of 2016. Crop response to treatment was measured in the terms of various quantitative and qualitative indices of plant growth like plant height, chlorophyll content, Number of tiller, penicle length and grain and straw yield, content of N, P and K in grain and straw were analyzed after harvest of the rice crop. The results revealed that the maximum grain yield (63.86 $\mathrm{q}$ $\mathrm{ha}^{-1}$ ) was recorded significantly in the treatment $\mathrm{T}_{3}$ (100\% of RDN through PCU 3 Split) and the maximum straw yield $\left(109.38 \mathrm{q} \mathrm{ha}^{-1}\right)$ was recorded in the treatment $\mathrm{T}_{10}(55 \%$ of RDN through PCU Single Basal + FYM + PGPR). The total biological yield was tent to slightly decrease with a decrease in fertilizer level and found statistical significance over treatment control $\mathrm{T}_{1}$.

\section{Introduction}

Rice (Oryza sativa L.) is one of the most important staple food crops for more than half of the world population, especially for southeastern Asia, where $90 \%$ of the world production of rice is grown and consumed. In India, it occupies 44 million ha of land and produces about 103.41 million tonnes of grain with the productivity of 2.35 tonnes $\mathrm{ha}^{-1}$ (Anonymous, 2012-13). However, this is not enough to feed the ever-increasing population, and there is need to increase the production to keep pace with population growth. On the contrary there is very limited scope for further expansion of area under rice and the only alternative left is vertical increase in yield. After onset of green revolution (1965-66), there has been remarkable increasein production of food grains due to intensive cultivation and enhanced use of agrochemicals - mainly fertilizers and pesticides, which has resulted in deterioration of soil quality. Intensive cultivation with high waterdemanding crops has led to a decrease in groundwater levels, serious water logging and secondary salinization in large parts of the Indo-Gangetic Plain (Rai, 2002; Ladha et al., 2003). Moreover, leveling of the yield increase, declining input factor productivity and even declining soil quality have been reported for parts of the Indo-Gangetic Plain 
(Narang and Virmani, 2001). Soil quality plays a key role in determining production capacity and thus it is one of the major indicators of sustainability of any cropping system. Soil quality decline is primarily due to nutrient depletion (larger removal than addition of nutrients), nutrient mining (large removal of nutrients and no inputs), acidification (decline in $\mathrm{pH}$ and/or an increase in exchangeable $\mathrm{Al}$ ), loss of organic matter and increase in toxic elements (e.g. Al, Mn). The microbial activities in soil also decrease due to reduced levels of organic matter. These microbial activities play significant role in nutrient availability and recycling. The decreased level of organic matter causes a strong reduction in soil fertility as it plays several roles in soil. Its deficiency results in poor physical, chemical and biological properties of soil.

Nitrogen $(\mathrm{N})$ is often the most important and most limiting nutrient for crop yield in many regions of the world. Nitrogenous fertilizer is one of the main inputs for cereals production systems. Nitrogen is the plant nutrient that is often most limiting to efficient and profitable crop production. Inadequate supply of available $\mathrm{N}$ frequently results in plants that have slow growth, low protein levels, poor yield of low quality produce, and inefficient water use. Therefore, application of nitrogen fertilizer at the right rate and time is vital for the enhancement of soil fertility and crop productivity. High levels of $\mathrm{N}$ supply results in a higher protein content, but increased efficiency of utilization is realized when concentration in the kernels increases and grain yield remains stable (Ortiz Monasterio et al., 1997).

Polymer-coated urea, also called plasticcoated urea, or PCU, is a slow releasing fertilizers can permit a more precise rate of nitrogen release Normal Urea. A variety of polymers are used to form semi-permeable coatings on soluble $\mathrm{N}$ sources, usually urea. Release is regulated by polymer chemistry, coating thickness, soil moisture, and soil temperature. Because of high cost, CRN use in agriculture is limited, accounting for less than $1 \%$ of worldwide fertilizer consumption (Englesjord et al., 1997). The disadvantage of polymer-coated urea products is their relatively high cost compared to Normal Urea. Polymer-coated urea fertilizers use a hydrophobic (water insoluble) coating that temporarily isolates the urea prill from the soil environment. These polymer coatings may be resins or mineral-based products that act as semipermeable membranes or impermeable membranes with tiny pores. Nutrient release through these membranes is controlled by the properties of the coating material, i.e., its permeability characteristics as affected by temperature and moisture. Thus, they are not significantly affected by soil properties such as $\mathrm{pH}$, salinity, soil texture, microbial activity, redox potential or cation exchange capacity. Therefore, it is possible to predict and control the nutrient release rate from these products are more accurately than for Normal Urea (Trenkel, 2010).

\section{Materials and Methods}

The experiment was carried out during kharif season of 2016 at the Agricultural Research Farm, Department of soil science and agricultural chemistry, Institute of Agricultural Sciences, Banaras Hindu University, Varanasi, Uttar Pradesh (India). The experimental trial was conducted in field number A/14 of Agricultural Research Farm, B.H.U. This experiment was conducted with 12 treatments and 3 replications of control, $100 \%$ of RDN through normal urea as a single basal dose and as in 3 split, and $100 \%$, $85 \%, 70 \%$ and $55 \%$ RDN through PCU as single basal doses and as in 3 split under randomized block design (RBD) on rice variety HUR-105 during kharif season 2016. 
The treatment $\left(\mathrm{T}_{12}\right)$ was comprising with $55 \%$ of RDN through PCU as basal dressing +2 tons FYM ha ${ }^{-1}+$ PGPR (mixture of Azotobactor chroococcum, Pseudomonas aeruginosa, Pseudomonas flurescens, Pseudomonas putida, Bacillus subtilis, Azospirillumbrasilense, Trichoderma harzianum). The soil of experimental field was low in organic carbon $(0.48 \%)$, medium available $\mathrm{N}\left(210.50 \mathrm{~kg} \mathrm{ha}^{-1}\right)$, medium available $\mathrm{P}$ (12.32 $\mathrm{kg} \mathrm{ha}^{-1}$ ) and low available $\mathrm{K}\left(198.5 \mathrm{~kg} \mathrm{ha}^{-1}\right)$ with $\mathrm{pH}(7.8)$ and EC (0.22 $\left.\mathrm{dSm}^{-1}\right)$.

\section{Growth parameters}

The height of plant was measured from the surface of soil to the tip of plant with the help of a meter scale at 40,80 and harvesting stage after transplanting. Chlorophyll content of the plants was measured by the use of Chlorophyll Meter in SPAD units at 40 and 60 days after transplanting. Chlorophyll content of randomly selected 5 sampled leaves from various rice plant in net plot area was measured at 40, 60 DAS coinciding with tillering, booting and panicle emergence stage of the crop. Finally, the average value on chlorophyll content were computed and expressed in SPAD unit.

\section{Yield attributes}

Numbers of tillers plant ${ }^{-1}$ were counted at 40 , 80 and harvesting days after transplanting of rice seedling. The grains yield obtained from each plot were weighed by pan balance in $\mathrm{kg}$ and converted into tons $\mathrm{ha}^{-1}$ by multiplying with factor 2.5. The grain yield was subtracted from the biological yield per plot to record the straw yield $\mathrm{kg} \mathrm{plot}^{-1}$. Which was converted into tons $\mathrm{ha}^{-1}$ by multiplying with factor 2.5. Biological Yield $\left(\mathrm{kg} \mathrm{ha}^{-1}\right)$ was calculated from all the above ground plants part of each net plot, sun dried and weight in $\mathrm{kg} \mathrm{plot}^{-1}$ and these values were expressed into $\mathrm{kg} \mathrm{ha}^{-1}$.

\section{Plant analysis}

The plant and grain samples collected at harvesting were dried at $60+2^{\circ} \mathrm{C}$ for $48 \mathrm{hrs}$ in a hot air oven and grind to powder. Nitrogen content in plant and grain samples was determined by Modified Kjeldahl Method as per procedure outlined by Gupta (2007). In a digestion tube, $0.5 \mathrm{~g}$ of powdered plant straw was taken and $10 \mathrm{~mL}$ of diacid solution $(9: 1$, $\mathrm{H}_{2} \mathrm{SO}_{4}: \mathrm{HClO}_{4}$ ) was added and kept overnight, $10 \mathrm{~g}$ of sulphate mixture (20 parts $\mathrm{K}_{2} \mathrm{SO}_{4}+1$ part catalyst mixture containing 20 parts $\mathrm{CuSO}_{4}+1$ part selenium powder) was added and heating was done in a digestion chamber till a clear colourless solution was obtained. The suspension was cooled and filtered through Whatman No. 42 filter paper in a 50 ml volumetric flask and volume was made up with distilled water. $10 \mathrm{~mL}$ of $4 \%$ boric acid solution containing bromocresol green and methyl red indicator was taken in a conical flask, outlet of distillation apparatus was dipped into boric acid solution. $5 \mathrm{~mL}$ of the aliquot was taken and transferred to distillation flask of micro-kjeldahl distillation apparatus and $10 \mathrm{~mL}$ of $40 \% \mathrm{NaOH}$ solution was added. After completion of distillation, boric acid was titrated against $0.02 \mathrm{~N} \mathrm{H}_{2} \mathrm{SO}_{4}$. Blank was also run. One gram dried and powdered (20 mesh) plant sample was taken in a $50 \mathrm{ml}$ digestion tube and $10 \mathrm{ml} \mathrm{di}$-acid mixture $\left(4: 1 \mathrm{v} / \mathrm{v} \mathrm{HNO}_{3}: \mathrm{HClO}_{4}\right)$ was added to it and was kept overnight. It was then digested on a block digester till a colourless solution was obtained. The volume of acid was reduced till the flask contained only moist residue. The flask was cooled and $25 \mathrm{~mL}$ of distilled water was added to it. The solution was filtered into a $50 \mathrm{~mL}$ volumetric flask and diluted up to mark. $2 \mathrm{ml}$ of digest was taken in a $25 \mathrm{ml}$ volumetric flask and 2 drops of 2,4 dinitrophenol indicator was added followed by ammonium solution till appearance of yellow colour. Now $6 \mathrm{~N} \mathrm{HCl}$ was added drop wise till it became colourless. $5 \mathrm{~mL}$ of Vanadate 
molybdate solution was then added to it and diluted to $25 \mathrm{~mL}$ with distilled water, mixed well and the intensity of yellow colour was read on spectrophotometer by using blue filter at $440 \mathrm{~nm}$ wave length. A blank was also run without $\mathrm{P}$ solution simultaneously. Phosphorus content in straw and grain was calculated using standard curve and expressed as total $\mathrm{P}-(\%)$.

Same procedure was followed in determination of $\mathrm{P}$ content in grain except the weight of sample in case of grain was only 0.2 g (Jackson 1967). Potassium content in plant and grain was determined by Flame Photometer Method (Jackson, 1973). Digested extract was used directly for flame photometric determination of potassium. K content was calculated using the standard curve and expressed as.

\section{Statistical analysis and interpretation of data}

The data recorded during the course of investigation were subjected to statistical analysis as described by Panse and Sukhatme (1985). The significant effect of treatments was judged with the help of ' $F$ ' (variance ratio) table. The significant differences between of the means were tested against critical differences at 5\% probability level.

Analysis of variance for all treatment in Randomized Block Design (RBD) was carried out. The significance and non-significant effect of the different treatments was tested with the help of ' $F$ ' variance ratio test. Calculated ' $F$ ' value was compared with table value of ' $F$ ' at $5 \%$ levels of significance.

If calculated value of ' $F$ ' exceeds its table value, the effect was considered to be significant. The significant difference between treatment means was tested using critical difference at $5 \%$ level of significance.

\section{Results and Discussion}

\section{Effect on plant height}

The data pertaining to effect of PCU and normal urea on height of plant is presented in Table 1 and depicted in. It is evident from The Table that height of plant (40 DAT) varied from 66.7 to $85.13 \mathrm{~cm}$. It was higher in treatment $\mathrm{T}_{3}(100 \%$ of RDN through PCU 3 Split) $85.13 \mathrm{~cm}$ followed by $\mathrm{T}_{12}(55 \%$ of RDN through PCU Single Basal + $40 \mathrm{Kg}$ P + FYM @ $2 \mathrm{t} \mathrm{ha}^{-1}+$ PGPR) $84.40 \mathrm{~cm}$. Significant differences were found between the treatments after application of PCU in the plot. The inoculation with PCU showed significantly higher plant height $(85.13 \mathrm{~cm})$ at 40 DAT than normal urea treated plot with three split and single basal dose are 75.33 and $74.07 \mathrm{~cm}$ respectively. The treatment $\mathrm{T}_{8}(100 \%$ PCU single basal dose) was found $84.20 \mathrm{~cm}$ plant height followed by $\mathrm{T}_{4}$ (85\% of RDN through PCU 3 Split) $82.20 \mathrm{~cm}$ and treatment $\mathrm{T}_{9}(85 \%$ of RDN through PCU Single Basal) was found $81.20 \mathrm{~cm}$ followed by $\mathrm{T}_{5}(70 \%$ of $\mathrm{RDN}$ through PCU 3 Split) $80.60 \mathrm{~cm}$. However, the treatment $\mathrm{T}_{10}(70 \%$ of RDN through PCU Single Basal), $\mathrm{T}_{6}$ (55\% of RDN through PCU 3 Split) and $\mathrm{T}_{11}$ (55\% of RDN through PCU Single Basal) were found statically at par to each other. Moreover, control plot with RDF showed a lowest plant height of $66.07 \mathrm{~cm}$ at 40 DAT. Almost similar trend was noticed with the plant height recorded at 80 DAT and at harvesting.

\section{Effect on chlorophyll content (SPAD value)}

Data pertaining to the chlorophyll content (SPAD value) in leaf as influenced by normal urea, PCU, SSP, FYM and PGPR application is give in Table 1. There was a significant increase in chlorophyll content at 40 DAT with the application of normal urea, PCU, SSP, FYM and PGPR. The maximum chlorophyll content (40.60) in leaf was found 
in treatment $\mathrm{T}_{3}$ (100\% of RDN through PCU 3 Split) followed by $\mathrm{T}_{8}(100 \%$ of RDN through PCU Single Basal) having a value 40.33. The minimum chlorophyll content (34.01) was found in treatment $\mathrm{T}_{1}$ (control). The application of FYM and PGPR with $40 \mathrm{~kg}$ P through SSP and $55 \%$ RDN through PCU Single Basal in $\mathrm{T}_{12}$, increase chlorophyll content $18.34 \%$ over the Control. Decreasing the percentage of PCU with three split application found at par in $\mathrm{T}_{4}(85 \%), \mathrm{T}_{5}(70 \%)$ and $\mathrm{T}_{6}(55 \%)$ and with single basal dose was found at par in $\mathrm{T}_{9}(85 \%), \mathrm{T}_{10}(70 \%)$ and $\mathrm{T}_{11}$ $(55 \%)$. Moreover, with normal urea in $\mathrm{T}_{2}$ (100\% of RDN through Urea 3 Split), $\mathrm{T}_{7}$ (100\% of RDN through Urea Single Basal) it was found similar valued 37.74 and 37.50 respectively. Almost similar trend was observed in chlorophyll content recorded at 60 DAT. GuJia Lin et al., (2009) The nitrogen release characteristic of macromolecule polymer coated urea (PCU) by laboratory method of water dissolve and the effects of applied PCU on tall fescue turf as basal application in spring was studied.

\section{Effect on number of tillers per hill}

A critical perusal of the data presented in Table 2 revealed that a significant increase was found in number of tillers at 40 DAT with the three split application of PCU than single basal dose of PCU and normal urea. While a significant increase in number of tillers also noted with single basal application of PCU with FYM, PGPR and SSP. Split application of PCU resulted significant increase in number of tillers (40 DAT) due to minimization of loss and higher nutrient efficiency as compared to single basal dose of PCU and other nutrient sources. The maximum number of tillers (29.33) was noted in $\mathrm{T}_{3}(100 \%$ of $\mathrm{RDN}$ through PCU 3 Split) and minimum number of tillers (15.22) in $\mathrm{T}_{1}$ (control) at $40 \mathrm{DAT}$. The application of PCU in treatment $\mathrm{T}_{8}(100 \%$ of RDN through PCU Single Basal) increases number of tillers $84.95 \%$ over the control,
whileT $_{12}(55 \%$ of RDN through PCU Single Basal + FYM + PGPR + SSP) increased $73.91 \%, \mathrm{~T}_{4}(85 \%$ of RDN through PCU 3 Split) increased $71.15 \%, \mathrm{~T}_{5}(70 \%$ of $\mathrm{RDN}$ through PCU 3 Split) increased $67.54 \%$ and $\mathrm{T}_{6}$ (55\% of RDN through PCU 3 Split) increased $59.32 \%$. However, the treatment $\mathrm{T}_{9}(85 \%$ of RDN through PCU Single Basal), $\mathrm{T}_{10}(70 \%$ of RDN through PCU Single Basal) and $\mathrm{T}_{11}$ (55\% of RDN through PCU Single Basal) and $\mathrm{T}_{10}(70 \%$ of RDN through PCU Single Basal) were found statically at par to each other. Furthermore, with application of urea at 100 $\%$ in single basal and 3 split application found lowest among all the treatment valued 17.73 and 18.01 respectively. Almost similarand increasing trend was noticed with the number of tillers recorded at 80 DAT and a similar but decreasing trend at harvesting as compared to 40 DAT.

\section{Effect on panicle length}

Data pertaining to the panicle length presented in table 2 showed that at 80 DAT maximum panicle length of $19.92 \mathrm{~cm}$ was recording with split application of PCU in $\mathrm{T}_{3}(100 \%$ of RDN through PCU 3 Split) and minimum panicle length of $15.60 \mathrm{~cm}$ in $\mathrm{T}_{1}$ (control). While an increase in panicle length recorded in $\mathrm{T}_{8}(100$ $\%$ of RDN through PCU Single Basal) 25.44 $\%$ over control, in $\mathrm{T}_{12}$ (55\% of RDN through PCU Single Basal + FYM + PGPR + SSP) $24.10 \%$ increase and in $\mathrm{T}_{4}(85 \%$ of $\mathrm{RDN}$ through PCU 3 Split) $22.50 \%$ increase. While comparing normal urea treated plot $8.52 \%$ increase over control in $\mathrm{T}_{2}(100 \%$ of $\mathrm{RDN}$ through Urea 3 Split) and in $\mathrm{T}_{7}(100 \%$ of RDN through Urea Single Basal) an increase of $4.93 \%$. Moreover, $\mathrm{T}_{5}(70 \%$ of $\mathrm{RDN}$ through PCU 3 Split), $\mathrm{T}_{6}(55 \%$ of RDN through PCU 3 Split), $\mathrm{T}_{9}$ (85\% of RDN through PCU Single Basal), $\mathrm{T}_{10}$ (70\% of RDN through PCU Single Basal) and $\mathrm{T}_{11}$ (55 $\%$ of RDN through PCU Single Basal) found at par. A similar trend was recorded at harvesting for panicle length. 
Table.1 Effect of different levels of recommended dose of nitrogen (RDN) through PCU on plant height and chlorophyll content (SPAD value) in leaves of rice at different days of interval

\begin{tabular}{|c|c|c|c|c|c|c|}
\hline \multicolumn{2}{|c|}{ Treatment } & \multicolumn{3}{|c|}{ Average Plant height hill ${ }^{-1}(\mathrm{~cm})$} & \multicolumn{2}{|c|}{$\begin{array}{l}\text { Chlorophyll in } \\
\text { leaves }\left(\mu \mathrm{g} \mathrm{ml} \mathbf{~ m}^{-1}\right)\end{array}$} \\
\hline & & 40 DAT & 80 DAT & $\begin{array}{c}\text { At } \\
\text { harvesting }\end{array}$ & 40 DAT & $\begin{array}{c}60 \\
\text { DAT }\end{array}$ \\
\hline $\mathbf{T}_{1}$ & Control & 32.82 & 76.09 & 81.30 & 25.83 & 24.61 \\
\hline $\mathbf{T}_{2}$ & $100 \%$ of RDN through Urea 3 Split & 39.33 & 96.77 & 94.20 & 33.15 & 31.99 \\
\hline $\mathbf{T}_{\mathbf{3}}$ & $100 \%$ of RDN through PCU 3 Split & 41.47 & 94.73 & 97.70 & 38.90 & 36.69 \\
\hline $\mathbf{T}_{4}$ & $85 \%$ of RDN through PCU 3 Split & 42.57 & 96.20 & 96.20 & 37.36 & 36.77 \\
\hline $\mathbf{T}_{\mathbf{5}}$ & $70 \%$ of RDN through PCU 3 Split & 43.07 & 91.70 & 94.57 & 38.40 & 36.31 \\
\hline $\mathrm{T}_{6}$ & $55 \%$ of RDN through PCU 3 Split & 40.20 & 91.43 & 88.30 & 35.10 & 33.30 \\
\hline $\mathbf{T}_{7}$ & $100 \%$ of RDN through Urea Single Basal & 38.67 & 84.93 & 89.13 & 39.35 & 38.31 \\
\hline $\mathbf{T}_{8}$ & $100 \%$ of RDN through PCU Single Basal & 41.07 & 95.47 & 91.50 & 38.88 & 37.93 \\
\hline $\mathrm{T}_{9}$ & $85 \%$ of RDN through PCU Single Basal & 41.17 & 94.83 & 93.53 & 40.35 & 37.60 \\
\hline $\mathbf{T}_{10}$ & $70 \%$ of RDN through PCU Single Basal & 42.33 & 95.00 & 98.57 & 39.03 & 36.00 \\
\hline $\mathbf{T}_{11}$ & $55 \%$ of RDN through PCU Single Basal & 40.47 & 95.53 & 97.13 & 36.57 & 35.08 \\
\hline $\mathbf{T}_{12}$ & $\begin{array}{l}55 \% \text { of RDN through PCU Single Basal } \\
+40 \mathrm{Kg} \mathrm{P}+\text { FYM @ } 2 \mathrm{t} \mathrm{ha}^{-1}+\text { PGPR }\end{array}$ & 36.70 & 92.43 & 96.53 & 36.41 & 34.17 \\
\hline & SEm \pm & 0.954 & 1.421 & 1.089 & 1.900 & 1.931 \\
\hline & $\mathrm{CD}$ at $5 \%$ & 1.974 & 2.941 & 2.253 & 3.934 & 3.998 \\
\hline
\end{tabular}

Table.2 Effect of different levels of RDN through PCU on No. of tillers and Panicle length of rice at different days of interval

\begin{tabular}{|c|c|c|c|c|c|c|}
\hline \multicolumn{2}{|r|}{ Treatment } & \multicolumn{3}{|c|}{ No. of tillers hill ${ }^{-1}$} & \multicolumn{2}{|c|}{ Panicle length (cm) } \\
\hline & & $\begin{array}{c}40 \\
\text { DAT }\end{array}$ & $\begin{array}{c}80 \\
\text { DAT }\end{array}$ & $\begin{array}{c}\text { At } \\
\text { harvesting }\end{array}$ & $\begin{array}{c}80 \\
\text { DAT }\end{array}$ & $\begin{array}{c}\text { At } \\
\text { harvesting }\end{array}$ \\
\hline$\overline{T_{1}}$ & Control & 15.22 & 24.52 & 23.02 & 15.60 & 16.72 \\
\hline $\mathbf{T}_{2}$ & $100 \%$ of RDN through Urea 3 Split & 18.01 & 26.43 & 25.11 & 16.93 & 17.81 \\
\hline $\mathbf{T}_{3}$ & $100 \%$ of RDN through PCU 3 Split & 29.33 & 34.96 & 33.65 & 19.92 & 20.90 \\
\hline $\mathbf{T}_{4}$ & $85 \%$ of RDN through PCU 3 Split & 26.05 & 32.13 & 31.09 & 19.11 & 20.15 \\
\hline $\mathbf{T}_{5}$ & $70 \%$ of RDN through PCU 3 Split & 25.50 & 31.91 & 30.27 & 18.94 & 19.90 \\
\hline $\mathrm{T}_{6}$ & $55 \%$ of RDN through PCU 3 Split & 24.25 & 30.40 & 29.57 & 18.70 & 19.53 \\
\hline $\mathbf{T}_{7}$ & $100 \%$ of RDN through Urea Single Basal & 17.73 & 25.67 & 24.56 & 16.37 & 17.35 \\
\hline $\mathbf{T}_{8}$ & $100 \%$ of RDN through PCU Single Basal & 28.15 & 34.07 & 33.60 & 19.57 & 20.68 \\
\hline $\mathbf{T}_{9}$ & $85 \%$ of RDN through PCU Single Basal & 25.31 & 31.67 & 30.53 & 18.77 & 19.59 \\
\hline $\mathbf{T}_{10}$ & $70 \%$ of RDN through PCU Single Basal & 25.07 & 30.20 & 29.38 & 18.37 & 19.79 \\
\hline $\mathbf{T}_{11}$ & $55 \%$ of RDN through PCU Single Basal & 23.70 & 29.47 & 28.35 & 17.96 & 18.93 \\
\hline $\mathbf{T}_{12}$ & $\begin{array}{l}55 \% \text { of RDN through PCU Single Basal + } \\
40 \mathrm{Kg} \mathrm{P}+\mathrm{FYM} @ 2 \mathrm{t} \mathrm{ha}^{-1}+\mathrm{PGPR}\end{array}$ & 26.47 & 33.11 & 32.34 & 19.36 & 20.20 \\
\hline & SEm \pm & 0.709 & 0.751 & 0.859 & 0.549 & 0.955 \\
\hline & CD at $5 \%$ & 2.080 & 2.203 & 2.518 & 1.609 & 2.802 \\
\hline
\end{tabular}


Table.3 Effect of different levels of RDN through PCU on yield of rice at harvesting

\begin{tabular}{|c|c|c|c|c|}
\hline \multirow{2}{*}{\multicolumn{2}{|c|}{ Treatment }} & \multicolumn{3}{|c|}{ Yield $\left(\mathrm{q} \mathrm{ha}^{-1}\right)$} \\
\hline & & Biological & Grain & Straw \\
\hline $\mathbf{T}_{1}$ & Control & 96.01 & 33.64 & 62.36 \\
\hline $\mathbf{T}_{2}$ & $100 \%$ of RDN through Urea 3 Split & 154.12 & 58.23 & 95.89 \\
\hline $\mathbf{T}_{3}$ & $100 \%$ of RDN through PCU 3 Split & 157.12 & 63.86 & 93.26 \\
\hline $\mathbf{T}_{4}$ & $85 \%$ of RDN through PCU 3 Split & 147.17 & 59.66 & 87.50 \\
\hline$T_{5}$ & $70 \%$ of RDN through PCU 3 Split & 150.90 & 50.87 & 100.03 \\
\hline$T_{6}$ & $55 \%$ of RDN through PCU 3 Split & 149.06 & 56.29 & 92.77 \\
\hline $\mathbf{T}_{7}$ & $100 \%$ of RDN through Urea Single Basal & 150.55 & 48.31 & 102.23 \\
\hline$\overline{T_{8}}$ & $100 \%$ of RDN through PCU Single Basal & 155.22 & 62.44 & 92.79 \\
\hline$T_{9}$ & $85 \%$ of RDN through PCU Single Basal & 161.67 & 56.26 & 105.41 \\
\hline$\overline{T_{10}}$ & $70 \%$ of RDN through PCU Single Basal & 160.96 & 51.58 & 109.38 \\
\hline$T_{11}$ & $55 \%$ of RDN through PCU Single Basal & 153.75 & 57.29 & 96.46 \\
\hline $\mathbf{T}_{12}$ & $\begin{array}{l}55 \% \text { of RDN through PCU Single Basal } \\
+40 \mathrm{Kg} \text { P + FYM @ } 2 \mathrm{t} \mathrm{ha}^{-1}+\text { PGPR }\end{array}$ & 164.59 & 61.77 & 102.82 \\
\hline & SEm \pm & 2.362 & 1.773 & 1.371 \\
\hline & CD at 5\% & 4.889 & 3.671 & 2.837 \\
\hline
\end{tabular}

Table.4 Content of N, P and K levels of recommended dose of nitrogen (RDN) through PCU in grain and straw of rice as affected by different $\mathrm{N}$ levels and methods of application through PCU and NU

\begin{tabular}{|c|c|c|c|c|c|c|c|}
\hline \multirow{2}{*}{\multicolumn{2}{|c|}{ Treatment }} & \multicolumn{3}{|c|}{ Content in grain } & \multicolumn{3}{|c|}{ Content in straw } \\
\hline & & $\mathbf{N}(\%)$ & $\mathbf{P}(\%)$ & $\mathbf{K}(\%)$ & $\mathbf{N}(\%)$ & $\mathbf{P}(\%)$ & $\mathbf{K}(\%)$ \\
\hline $\mathbf{T}_{1}$ & Control & 0.890 & 0.237 & 0.131 & 0.307 & 0.092 & 1.092 \\
\hline $\mathbf{T}_{2}$ & $100 \%$ of RDN through Urea 3 Split & 1.122 & 0.249 & 0.187 & 0.341 & 0.105 & 1.237 \\
\hline $\mathbf{T}_{3}$ & $100 \%$ of RDN through PCU 3 Split & 1.234 & 0.316 & 0.228 & 0.451 & 0.148 & 1.328 \\
\hline $\mathbf{T}_{4}$ & $85 \%$ of RDN through PCU 3 Split & 1.133 & 0.278 & 0.219 & 0.381 & 0.132 & 1.303 \\
\hline $\mathbf{T}_{5}$ & $70 \%$ of RDN through PCU 3 Split & 1.128 & 0.268 & 0.213 & 0.364 & 0.128 & 1.298 \\
\hline$T_{6}$ & $55 \%$ of RDN through PCU 3 Split & 1.124 & 0.261 & 0.208 & 0.342 & 0.125 & 1.287 \\
\hline $\mathbf{T}_{7}$ & $100 \%$ of RDN through Urea Single Basal & 1.119 & 0.247 & 0.185 & 0.332 & 0.103 & 1.232 \\
\hline $\mathbf{T}_{8}$ & $100 \%$ of RDN through PCU Single Basal & 1.231 & 0.313 & 0.225 & 0.449 & 0.145 & 1.323 \\
\hline$T_{9}$ & $85 \%$ of RDN through PCU Single Basal & 1.130 & 0.273 & 0.216 & 0.375 & 0.129 & 1.296 \\
\hline$T_{10}$ & $70 \%$ of RDN through PCU Single Basal & 1.126 & 0.262 & 0.208 & 0.353 & 0.126 & 1.279 \\
\hline $\mathrm{T}_{11}$ & $55 \%$ of RDN through PCU Single Basal & 1.117 & 0.258 & 0.202 & 0.340 & 0.122 & 1.268 \\
\hline$\overline{T_{12}}$ & $\begin{array}{l}55 \% \text { of RDN through PCU Single Basal + } \\
40 \mathrm{Kg} \text { P + FYM @ } 2 \mathrm{t} \mathrm{ha}^{-1}+\text { PGPR }\end{array}$ & 1.207 & 0.302 & 0.221 & 0.410 & 0.136 & 1.318 \\
\hline & SEm \pm & 0.026 & 0.004 & 0.008 & 0.018 & 0.007 & 0.020 \\
\hline & CD at $5 \%$ & 0.075 & 0.013 & 0.024 & 0.054 & 0.021 & 0.059 \\
\hline
\end{tabular}


Effect of different levels of recommended dose of nitrogen (RDN) through PCU and $\mathrm{NU}$ on biological, grain and straw yield of rice

A critical perusal of the data presented in table 3 revealed that the grain yield of rice was ranging from $33.64 \mathrm{q} \mathrm{ha}^{-1}$ to $63.86 \mathrm{q} \mathrm{ha}^{-1}$ and it has increased significantly with the split application of PCU at different levels. The maximum grain yield $\left(63.86 \mathrm{qha}^{-1}\right)$ was recorded in the treatment $\mathrm{T}_{3}(100 \%$ of $\mathrm{RDN}$ through PCU 3 Split) which was 9.66\% higher than treatment $\mathrm{T}_{2}(100 \%$ of $\mathrm{RDN}$ through Urea 3 Split) and $2.27 \%$ higher than $\mathrm{T}_{8} \quad(100 \%$ of RDN through PCU Single Basal). The treatment $\mathrm{T}_{3}$ (100\% of RDN through PCU 3 Split) was found $89.83 \%$ and $3.38 \%$ higher over the treatment $\mathrm{T}_{1}$ (control) and $\mathrm{T}_{12}(55 \%$ of RDN through PCU Single Basal+ FYM +PGPR +SSP) respectively. The treatment $\mathrm{T}_{11}(55 \%$ of RDN through PCU Single Basal) gave 57.29 qha $^{-1}$ grain yield which was $1.77 \%$ higher over the $\mathrm{T}_{6}(55 \%$ of RDN through PCU 3 Split). Treatment $\mathrm{T}_{4}$ (85 $\%$ of RDN through PCU 3 Split) gave $77.34 \%$ and $6.04 \%$ higher grain yield over the $\mathrm{T}_{1}$ (control) and $\mathrm{T}_{9}(85 \%$ of RDN through PCU Single Basal) respectively. However, Treatment $\mathrm{T}_{10}$ (70\% of RDN through PCU Single Basal) gave $53.32 \%$ and $1.39 \%$ higher grain yield over the $\mathrm{T}_{1}$ (control) and $\mathrm{T}_{5}$ (70 \% of RDN through PCU Single Basal) respectively. The total biological yield tent to slightly decrease with decrease the fertilizer level and found statistical significance over treatment control $\mathrm{T}_{1}$ presented in table 3 . It ranges from $96.01 \mathrm{q} \mathrm{ha}^{-1}$ and $164.59 \mathrm{q} \mathrm{ha}^{-1}$ from treatment $\left(\mathrm{T}_{1}\right)$ to treatment $\left(\mathrm{T}_{12}\right)$ respectively. The treatment $\left(\mathrm{T}_{10}\right)$ was found significantly $109.82 \%$ higher than the treatment control $\left(\mathrm{T}_{1}\right)$. However, among the all the maximum biological yield and straw yield was found in the treatment $\left(T_{12}\right)$ and maximum yield value occurred in the treatment $\left(\mathrm{T}_{1}\right)$. These treatments are statistically significant over treatment control $\left(\mathrm{T}_{1}\right)$. Singh et al., (1995) reported that grain yield of lowland wheat from a single application of polymer coated urea (PCU) was equivalent to or better than 3-4 time split application of urea. Fertilizer recovery with PCU was $70-75 \%$ compared to $50 \%$ with prilled urea.

Effect of different levels of recommended dose of nitrogen (RDN) through PCU and $\mathrm{NU}$ on content of nutrients in grain and straw

Nitrogen, phosphorus and potassium content in grain and straw

A critical observation of the data given in Table 4 marks it clear that effect of application of PCU, UREA, FYM and PGPR on nitrogen content in rice grain varied significantly. The higher $\mathrm{N}$ content in grain followed in treatment $\mathrm{T}_{3}(1.23 \%)$ and lower $\mathrm{N}$ content in grain followed in treatment $\mathrm{T}_{1}$ $(0.89 \%)$. The maximum content of nitrogen in grain was found in $\mathrm{T}_{3}(100 \%$ of $\mathrm{RDN}$ through PCU 3 Split), which was $10.27 \%$ higher over $\mathrm{T}_{7}(100 \%$ of RDN through Urea Single Basal), $9.98 \%$ higher over $\mathrm{T}_{2}(100 \%$ of RDN through Urea 3 Split), $8.91 \%$ higher over $\mathrm{T}_{4}(85 \%$ of RDN through PCU 3 Split), $2.23 \%$ higher over $\mathrm{T}_{12}$ (55\% of RDN through PCU Single Basal + FYM + PGPR) and $0.24 \%$ higher over $\mathrm{T}_{8}(100 \%$ of RDN through PCU Single Basal). The higher N content in straw followed in treatment $\mathrm{T}_{3}$ $(0.45 \%)$ and lower $\mathrm{N}$ content in straw followed in treatment $\mathrm{T}_{1}(0.31 \%)$. Spilt application of PCU showed significantly higher nitrogen content in straw $(0.45 \%)$ over control $\left(\mathrm{T}_{1}\right)$. The maximum content of nitrogen in straw was found in $\mathrm{T}_{3}(100 \%$ of RDN through PCU 3 Split), which was 36.36 $\%$ higher over higher over $\mathrm{T}_{7}(100 \%$ of RDN through Urea Single Basal), $32.35 \% \mathrm{~T}_{2}$ (100\% of RDN through Urea 3 Split), 18.42 
$\%$ higher over $\mathrm{T}_{4}(85 \%$ of RDN through PCU 3 Split), $9.75 \%$ higher over $\mathrm{T}_{12}(55 \%$ of RDN through PCU Single Basal + FYM + PGPR) and $2.27 \%$ higher over $\mathrm{T}_{8}(100 \%$ of RDN through PCU Single Basal). The maximum $\mathrm{P}$ content in grain followed in treatment $\mathrm{T}_{3}(0.32 \%)$ and minimum $\mathrm{P}$ content in treatment $\mathrm{T}_{1}(0.24 \%)$. The treatment $\mathrm{T}_{3}(100 \%$ of RDN through PCU 3 Split) $33.33 \%$ was found increase the phosphorus content in rice grain over the treatment $\mathrm{T}_{1}$ (control) while $\mathrm{T}_{8}(100 \%$ of RDN through PCU Single Basal) showed $29.16 \%$ over the treatment $\mathrm{T}_{1}$ (control). The inoculation of PGPR $\left(\mathrm{T}_{12}\right)$ significantly increases the phosphorus content in rice grain $25 \%$ over $\mathrm{T}_{1}$ but less than that of $\mathrm{T}_{3}$. The higher $\mathrm{P}$ content in straw followed in treatment $\mathrm{T}_{3}(0.15 \%)$ and lower $\mathrm{P}$ content in straw followed in treatment $\mathrm{T}_{1}(0.09 \%)$. The treatment $\mathrm{T}_{3}(100 \%$ of RDN through PCU 3 Split) $66.66 \%$ was found increase the phosphorus content in straw over the treatment $\mathrm{T}_{1}$ (control). "The inoculation of $\mathrm{PGPR}+\mathrm{FYM}+\mathrm{SSP} \quad\left(\mathrm{T}_{12}\right) \quad$ significantly increases the phosphorus content in wheat straw $55.55 \%$ over control $\left(\mathrm{T}_{1}\right)$. The higher $\mathrm{K}$ content in grain followed in treatment $\mathrm{T}_{3}(0.23$ $\%$ ) and lower $\mathrm{K}$ content in grain followed in treatment $\mathrm{T}_{1}(0.13 \%)$. The treatment $\mathrm{T}_{3}$ (100\% of RDN through PCU 3 Split) and $\mathrm{T}_{8}$ (100\% of RDN through PCU Single Basal) $76.92 \%$ was found increase the potassium content in grain over the treatment $\mathrm{T}_{1}$ (control), $21.05 \%$ higher over $\mathrm{T}_{2}(100 \%$ of RDN through Urea 3 Split) and $\mathrm{T}_{7}(100 \%$ of RDN through Urea Single Basal) respectively. While $\mathrm{T}_{12}(55 \%$ of $\mathrm{RDN}$ through PCU Single Basal+ FYM + PGPR + SSP) increased the grain $\mathrm{K}$ content $0.22 \%$. The higher potassium content in straw (1.33 $\%$ ) was obtained with the split application of $100 \%$ PCU in $\mathrm{T}_{3}$, The lowest potassium content in straw $(1.1 \%)$ was recorded in the treatment $\mathrm{T}_{1}$ (control). The treatment $\mathrm{T}_{3}(100$ $\%$ of RDN through PCU 3 Split) and $\mathrm{T}_{8}(100$
$\%$ of RDN through PCU Single Basal) $20.9 \%$ and $82.84 \%$ was found increase the potassium content in straw over the treatment $\mathrm{T}_{1}$ (control). Among the all the treatment the $\mathrm{N}, \mathrm{P}$ and $\mathrm{K}$ content in grain and straw the maximum content in treatment $\left(\mathrm{T}_{3}\right)$ which is significant over the control treatment $\left(\mathrm{T}_{1}\right)$.

In the present investigation, the treatment involving three split application of $70 \%$ of RDN through polymer coated urea showed a significant increase in plant height at 40 DAS. The treatment $\mathrm{T}_{2}(100 \%$ of RDN through urea 3 split) showed a significant increase in plant height at 80 DAS. But at harvesting stage maximum height of plant was due to treatment $\mathrm{T}_{3}(100 \%$ of RDN through PCU 3 split). The increases in number of tillers at 40 , 80 DAS and harvesting stage was significantly higher over control due to treatment $\mathrm{T}_{2} \quad(100 \%$ Urea three split application). The treatment $\mathrm{T}_{10}(70 \%$ of RDN through Urea single basal) and treatment $\mathrm{T}_{7}$ (100\% of RDN through PCU single basal) showed significantly higher SPAD value over control at 40 DAS and 80 DAS respectively. Application of PCU and urea found significantly effective to enhance grain and straw yield of rice. The maximum grain yield $\left(\mathrm{q} \mathrm{ha} \mathrm{h}^{-1}\right)$ was obtained when $100 \%$ of nitrogen was applied through PCU in split doses $\left(\mathrm{T}_{3}\right)$ which registered significant over control and other treatment. Only those treatments which received split application of PCU showed significantly higher $\mathrm{N}$ content in the rice grains than the control. $\mathrm{N}$ content was varying in grain from $12.34 \mathrm{mg} \mathrm{kg}^{-1}$ and in straw from 30.77 to $45.1 \mathrm{mg} \mathrm{kg}^{-1}$ significantly higher over control and treatments of receiving split and single basal doses of urea. The result of the present investigation conferred that a significant increase in grain and straw yield of rice along with other growth and yield attribute, N, P and $\mathrm{K}$ content and uptake by rice crop can be obtained with application of PCU over urea. Thus, $\mathrm{N}$ nutrition via PCU in 
split application of the rice crop holds immense importance for obtaining better growth and productivity. Increasing $\mathrm{N}$ concentration in rice grains is important to address the health problem of nutrient deficient food grain and malnutrition besides better crop production. Split application of PCU in the soil at sowing and at maximum tillering and milking stage was most effective for enriching the grains with $\mathrm{N}$ and to obtain the better bioavailability of the polymer coated N. However, for maximum grain yield, 3 split application of $100 \%$ PCU of treatment $\mathrm{T}_{3}$ hold promise. Therefore, application of treatment $100 \%$ of RDN through PCU 3 split may be recommended to the farmer, after its further testing on their own field, for better growth and yield of rice.

\section{References}

Bishop, R.T. (1993). Increased efficiency of nitrogen fertilizers when combined with polymers. Agronomy Journal, 67: 5356.

Bishop, R.T. (1998). Interaction between polymer coated nitrogen fertilizers and rainfall on vegetative growth versus ripening. Agronomy Journal, 72: 159164.

Bouwman, A. F., Boumans, L. J. M. and Batjes, N. H. (2002). Modeling global annual $\mathrm{N}_{2} \mathrm{O}$ and $\mathrm{NO}$ emissions from fertilized fields. Global Biogeochemical Cycles, 16(4).

Bouyoucos, G. J. (1962). Hydrometer method improved for making particle size analyses of soils. Agronomy journal, 54(5): 464-465.

Chen Yi, Wang ShengJia, Wang JiaYu. (2002). Effect of polymer-coated urea on chlorophyll and activities of some enzymes and fractionation of amino acids in rice plants. Acta Agriculture Zhejiangensis; 14(3): 167-171.
Chopra S. L. and Kanwar J. S. (1982). Analytical agricultural chemistry Kalyani Publishers. Ludhiana, India.

Craswell, E.T. and Vlek, P.G.L. (1979). Fate of fertilizer nitrogen applied in wetland rice. In: Freney and Simpson (eds.), Gaseous loss of nitrogen from plant soil systems. Developments in plant and soil sciences, 9: 237-268.

Engelsjord, M. E. and Singh, B. R. (1997). Effects of slow-release fertilizers on growth and on uptake and leaching of nutrients in Kentucky bluegrass turfs established on sand-based root zones. Canadian journal of plant science, 77(3): 433-444.

Gagnon, B., Ziadi, N. and Grant, C. (2012). Urea fertilizer forms affect grain corn yield and nitrogen use efficiency. CanadianjournalSoil Science, 92: 341351.

Giller, K.E., Chalk P.M., Dobermann A, Hammond L.C., Heffer P., Ladha J.K., Nyamudeza P., Maene L.M., Sali H., and Freney J.R. (2004). Emerging technologies to increase the efficiency of use of fertilizer nitrogen. p. 35-52. In A.R. Mosier et al., (ed.) Agriculture and the nitrogen cycle: assessing the impacts of fertilizer use on food production and the environment. Scope 65 Island Press, Washington, D.C.

GuJia Lin, Wang Chong Wang, Li Yu Quan, Yi Wen Ping, Li Ya Xing and Yang Yi Bin. (2010). Nitrogen release characteristics of coated urea and its effect on spring maize with touching application. Plant Nutrition and Fertilizer Science, 16(6): 1486-1491

Haderlein, L., Jensen, T.L., Dowbenko, R.E., and Blaylock, A.D. (2001). Controlled release urea as a nitrogen source for spring wheat in Western Canada: yield, grain $\mathrm{N}$ content, and Nitrogen use efficiency, 2:114-21. 
Jackson, M.L. (1973). Soil chemical analysis. Prentice Hallo of India Ltd., New Delhi, 183-204.

Jun-gang, Y., Xiao-hui, N.I., Kai, X.U., Junxiang, X.U., Bing, CAO, Bao-cun, LIU. (2010). Effects of co-situs application of polymer coated fertilizers on grain yield, root distribution and soil residual Nmin in summer maize. Plant Nutrition and Fertilizer Science, 16(4): 924-930.

Lyu, XiaoXiao, Yang YueChao, Li YunCong, Fan XiaoHui, Wan YongShan, GengYuQing, Zhang Min. (2015). Polymer-coated tablet urea improved rice yield and nitrogen use efficiency. Agronomy Journal, 107(5):1837-1844.

Moll, R.H., Kamprath, E.J. and Jackson, W.A. (1982).Analysis and interpretation of factors which contribute to efficiency of nitrogen utilization, Agronomy Journal, 74: 562-564.

Nash, P.R., Nelson, K.A. and Motavalli, P.P. (2013). Corn yield response to polymer and non-coated urea placement and timings. International Journal of Plant Production, 7(3): 373-392.

Saradha, P. (2005). A method for the calculation of time of last productive tiller formation in rice. Journal of Ecobiology, 17(6): 501-508.

Saradha, P. (2006). Chlorophyll meter (SPAD meter) - a non-destructive method of assessing nitrogen concentration of standing rice crop. Journal of Ecobiology, 18(2): 133-141. 17.

Subbiah, B.V. and Asija, G.L. (1956) A rapid procedure for the determination of available nitrogen in soil. Current Science 25: 259-260.

Tilman, D., Cassman, K. G., Matson, P. A., Naylor, R. and Polasky, S. (2002). Agricultural sustainability and intensive production practices. Nature, 418(6898): 671-677.

Trenkel, M. E. (2010). Slow-and controlledrelease and stabilized fertilizers: An option for enhancing nutrient use efficiency in agriculture. IFA, International fertilizer industry association.

Trenkel, M.E. (2010). Slow and controlledrelease and stabilized fertilizers. International Fertilizer Industry Association (IFA). Paris, France.

Vitousek, P. M., Aber, J. D., Howarth, R. W., Likens, G. E., Matson, P. A., Schindler, D. W. and Tilman, D. G. (1997). Human alteration of the global nitrogen cycle: sources and consequences. Ecological applications, 7(3): 737-750.

Walkley, A. and Black, C.A. (1934) an examination of the Degtjareff method for determining soil organic matter, and a proposed modification of the chromic acid titration method. Soil Science 37: 29-38.

Zhang, M., Nyborg, M., Malhi, S.S. and Solberg, E.D. (2000a). Yield and protein content of barley as affected by release rate of coated urea and rate of nitrogen application. Journal of Plant Nutrition, 23: 401-412.

\section{How to cite this article:}

Ravindra Meena, Janardan Yadav and Giriraj. 2018. Effect of Different Levels, Sources and Methods of Nitrogen Application on Growth and Yield of Rice (Oryza sativa L.). Int.J.Curr.Microbiol.App.Sci. 7(04): 102-112. doi: https://doi.org/10.20546/ijcmas.2018.704.012 